\title{
Simulations of the last interglacial and the subsequent glacial inception with the Planet Simulator
}

Simulating last interglacial and glacial inception

M. Donat and F. Kasper

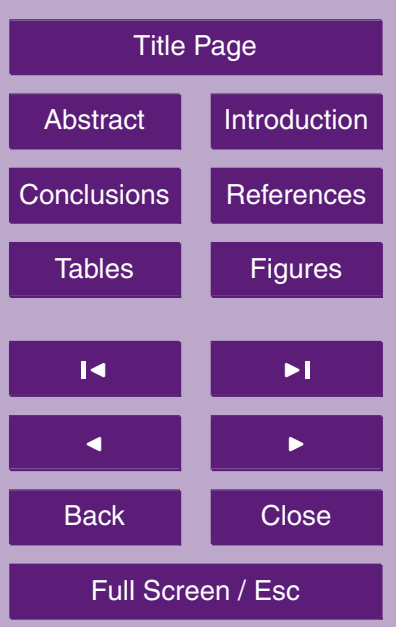

Printer-friendly Version

Interactive Discussion 


\section{Abstract}

The Planet Simulator was used to perform equilibrium simulations of the Eemian interglacial at $125 \mathrm{kyBP}$ and the glacial inception at $115 \mathrm{kyBP}$. Additionally, an accelerated transient simulation of that interval was performed. During this period the changes 5 of Earth's orbital parameters led to a reduction of summer insolation in the northern latitudes. The model has been run in different configurations in order to evaluate the influence of the individual sub-models. The strongest reaction on the insolation change was observed when the atmosphere was coupled with all available sub-systems: a mixed-layer ocean and a sea-ice model as well as a vegetation model. In the simulais higher compared to the preindustrial reference run and almost no perennial snow cover occurs. In the run for the glacial inception, wide areas in mid and high northern latitudes show negative temperature anomalies and wide areas are covered by snow or ice. The transient simulation shows that snow volume starts to increase after sum15 mer insolation has fallen below a critical value. The main reason for the beginning glaciation is the locally reduced (summer) temperature as a consequence of reduced summer insolation. Therefore, a larger fraction of precipitation falls as snow and less snow can melt. That mechanism is amplified by the snow-albedo-feedback.

\section{Introduction}

20 According to Milankovich (1941), variations of the Earth's orbit lead to changes in insolation. He suggested that decreased insolation in high latitudes during summer would be the most important factor for a glacial inception.

In this study the Planet Simulator (Fraedrich et al., 2005), a general circulation model (GCM) of reduced complexity has been applied to simulate the climate of the Eemian interglacial (125 kyBP) and the subsequent glacial inception (115 kyBP). These dates

${ }^{1}$ available at http://www.mi.uni-hamburg.de/plasim

1348
2, 1347-1369, 2006

Simulating last interglacial and glacial inception

M. Donat and F. Kasper

Title Page

Abstract

Introduction

Conclusions

References

Tables

Figures

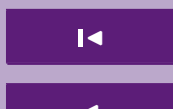

4

Back

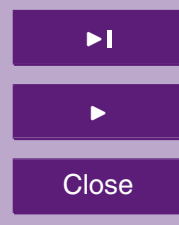

Full Screen / Esc

Printer-friendly Version

Interactive Discussion 
represent periods with increased and weakened seasonality of insolation on the northern hemisphere, caused by a change of the orbital parameters (Berger, 1978). At $125 \mathrm{kyBP}$ insolation in mid and high northern latitudes during (northern) summer was significantly higher compared to present day values; in winter it was lower. At $115 \mathrm{kyBP}$ 5 seasonality of northern hemispheric insolation was reduced. Insolation was significantly lower than today in mid and high northern latitudes during (northern) summer and was higher during winter. For a detailed discussion of insolation patterns during interglacials see Berger et al. (2006).

A set of experiments with different models have already been performed to simu10 late the transition from the latest interglacial period into the subsequent glacial period. Atmosphere-only-GCMs which were used in early experiments failed to successfully simulate a glacial inception. For a detailed review see Vettoretti and Peltier (2004). Khodri et al. (2001) as well as Vettoretti and Peltier (2003) performed experiments with coupled atmosphere-ocean models. Both studies came to the conclusion that 15 the ocean acts as a positive feedback mechanism for glacial inception. Without such a feedback, models do not succeed in simulating an significant increase of the snowand ice-cover in high northern latitudes. Recent experiments with coupled GCMs (Kaspar and Cubasch, 2006) and also EMICs (Kubatzki et al., 2006) showed that models succeed to simulate the glacial inception when the atmosphere is coupled to an oceanor ice-sheet-model. However, the application of various types of models led to different conclusions about details of the glaciation process. It is therefore of interest to compare the behaviour of diverse models. Compared to other types of models the Planet Simulator combines several advantages. Compared to typical EMICs, the atmospheric component is more comprehensive (Fraedrich et al., 2005), operates with 25 more regional details and is therefore more similar to a GCM. Compared to GCMs, the Planet Simulator has the advantage that it allows to couple different sub-systems and that it is computational much more efficient. It can therefore be used to run large sets of sensitivity experiments.
$2,1347-1369,2006$

\section{Simulating last interglacial and glacial inception}

M. Donat and F. Kasper Title Page

Abstract Introduction Conclusions References

Tables Figures
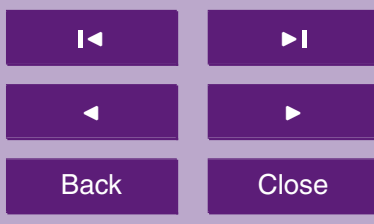

Back

Close

Printer-friendly Version

Interactive Discussion 


\section{Model description and experimental setup}

The central component of the Planet Simulator is an atmospheric GCM, that solves the basic dynamics. The applied version operates at a resolution of T21 (approx. 5.6 ${ }^{\circ}$ ) and on 5 vertical levels. The dynamical core of the Planet Simulator is based on the 5 moist primitive equations representing the conservation of momentum, mass and energy (Fraedrich et al., 2005). The set of equations consists of prognostic equations for the vertical component of the vorticity and the horizontal divergence, the first law of thermodynamics, equation of state (with hydrostatic approximation), continuity equation and a prognostic equation for water vapour (specific humidity). The atmosphere 10 can be coupled to a mixed-layer ocean, a sea-ice model and a vegetation model. The Planet Simulator has been developed at the University of Hamburg and has been designed as an efficient tool to run simulations with low computing costs. On a standard single-CPU PC (Intel Pentium 4, 2.4 GHz) about 100 years can be simulated per day. Thus, it is possible to run a number of experiments and also a transient simulation of 15 the 10000 year period.

Sensitivity tests with different configurations of the model have been performed in order to explore the influence of the sub-models. Table 1 gives an overview of the simulations and their configuration. The orbital parameters and thus the insolation are calculated according to Berger (1978) and refer to the year 1950. For each configuration, three simulations were performed: one with the insolation of 125000 years BP (hereafter labelled with $125 \mathrm{ky})$, another with insolation of 115000 years BP $(115 \mathrm{ky})$ and as preindustrial reference a run with today's insolation $(R E F)$. The latter is approximately equal to preindustrial values due to the relatively long periods of the varying orbital parameters. The atmospheric $\mathrm{CO}_{2}$ concentration was fixed to a preindustrial value of lies to the changed orbital parameters. Moreover, this is justifiable because the $\mathrm{CO}_{2}$ concentrations differ only slightly at the three regarded periods (Petit et al., 1999).
2, 1347-1369, 2006

Simulating last interglacial and glacial inception

M. Donat and F. Kasper Title Page

Abstract Introduction Conclusions References

Tables Figures

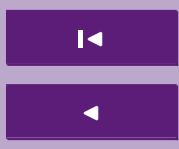
$>I$

\section{Full Screen / Esc}

Printer-friendly Version

Interactive Discussion 


\section{Influence of the coupled sub-systems}

The simulations in this and the following section were performed as equilibrium runs. Compared to more complex climate models, the Planet Simulator reaches an equilibrium state relatively fast. In the simulations with not more than one coupled sub-model

5 an equilibrium was reached within 20 years. These experiments were performed for 50 years in order to have a stable period for calculating climatological means. The stabilization took longer when the atmospheric component was coupled to the vegetation model in combination with the ocean and sea-ice model. Therefore, these simulations were carried out for 300 years.

10 Figure 1 shows the global mean temperatures of the different simulations. When only one of the subsystems is coupled, the model reacts with a temperature reduction for all periods. However, when all subsystems are active the reaction is much stronger than the sum of the single effects. This illustrates the nonlinearity of the system.

15 At least slightly lower temperatures are simulated for $115 \mathrm{kyBP}$ in all experiments in which the atmosphere is coupled to one or more sub-models (compared to $125 \mathrm{kyBP}$ and the reference run). Only the experiment with the uncoupled atmosphere produces almost identical temperature values for the different insolation conditions. This confirms the experiences that without an additional feedback the atmosphere-only-GCM will not succeed in simulating the cold state. The configuration with all sub-systems activated shows the strongest reaction on the change in insolation and results in a difference of $0.7 \mathrm{~K}$ in the global mean temperature between $125 \mathrm{ky}$ and $115 \mathrm{ky}$.

If the calculation of the mean temperature is restricted to the mid and high northern latitudes $\left(50^{\circ} \mathrm{N}-80^{\circ} \mathrm{N}\right)$, the differences between the simulations are significantly greater.

25 For example, in the AOV-configuration a difference of more than $4 \mathrm{~K}$ between $125 \mathrm{ky}$ and $115 \mathrm{ky}$ is simulated for this region.

In the following section we analyze the simulated climate for the different periods in detail. The focus is on the simulations with all sub-models activated (AOV), i.e. in which
2, 1347-1369, 2006

Simulating last interglacial and glacial inception

M. Donat and F. Kasper

Title Page

Abstract

Introduction

Conclusions

References

Tables

Figures

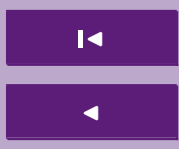

$\Delta$

Back

$\checkmark$

Close

Full Screen / Esc

Printer-friendly Version

Interactive Discussion 


\section{Detailed analysis of the simulated climates in the equilibrium runs}

The results presented in this section are all based on the last 30 years of the AOVsimulations. Thus, the values are considered as climatological means of the equilibrium 5 states.

\subsection{Near-surface temperature}

Globally and on the northern hemisphere, the annual cycle of the near-surface temperature (not shown) reflects the seasonal distribution of insolation. While for the $125 \mathrm{ky}$ run the seasonal difference of the global mean temperature is approximately $5 \mathrm{~K}$, the

difference between summer and winter temperature is less than $3 \mathrm{~K}$ for the $115 \mathrm{ky}$-run, associated with a considerably lower (northern) summer temperature (approximately $2 \mathrm{~K}$ cooler than $125 \mathrm{ky}$ ). This stronger seasonality for $125 \mathrm{ky}$ can also be seen when only the northern hemisphere or especially the high northern latitudes are regarded. In these latitudes, during all months of the year the temperatures of the $115 \mathrm{ky}$-run are lower than those of the $125 \mathrm{ky}$-run, even during the winter months, when insolation is higher. One reason for this is the wider snow cover in this area which will be analyzed later in this text.

In Fig. 2 the global distribution of the annual and seasonal (DJF, JJA) temperature anomalies of the runs $115 \mathrm{ky}$ and $125 \mathrm{ky}$ are shown relative to the preindustrial reference $R E F$. The temperatures differ between the simulations particularly on the northern hemisphere, and here especially over land areas.

The annual means of the $125 \mathrm{ky}$-run show positive temperature anomalies of 1 to $2 \mathrm{~K}$ over wide continental parts and the Arctic region, while the land areas in the equatorial regions are cooler. Temperature anomalies over the ocean areas are smaller.
2, 1347-1369, 2006

\section{Simulating last interglacial and glacial inception}

M. Donat and F. Kasper

Title Page

Abstract Introduction

Conclusions References

Tables Figures
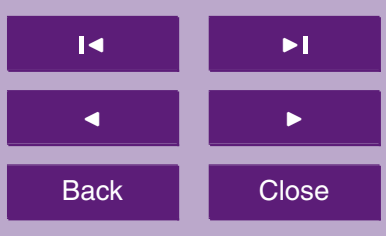

Back

Close

Full Screen / Esc

Printer-friendly Version

Interactive Discussion 
nents, compared to the preindustrial reference (Fig. 2c). This is a direct consequence of the stronger insolation (because of the reduced distance between Earth and Sun as well as the stronger obliquity).

During (northern) winter (DJF) most parts of the continental areas respond to the de5 crease in insolation - the Earth passes at this time its aphelion - and show lower temperatures compared to the reference run (Fig. 2e). Positive temperature anomalies are simulated only northwards of $60^{\circ} \mathrm{N}$. They are related to the far lower snow and ice cover, which will be discussed in the following subsection.

As about $2 / 3$ of the land area are located on the northern hemisphere and the reaction 10 on the modified insolation is much stronger on land than over the (mixed-layer) ocean, temperature anomalies on the northern hemisphere are greater than on southern.

In case of the $115 \mathrm{ky}$-simulation significant cooling occurs at the mid and high northern latitudes (Fig. 2b). These negative temperature anomalies are not restricted to land areas. Lower temperatures are also simulated over the northern parts of the Pacific and the Atlantic due to the increased permanent sea-ice cover in these regions.

The strong negative temperature anomalies in the mid and high northern latitudes are also visible when the means are calculated for the summer and accordingly winter months (Fig. $2 \mathrm{~d} / \mathrm{f}$ ). Northwards of about $40^{\circ} \mathrm{N}$, temperatures over continents and oceans are lower compared to the preindustrial reference. During the (northern) summer months - when the insolation is lower than in today's summers - this cooling is particularly strong. The anomalies of the winter temperature - when insolation is higher than today - are smaller, but still negative.

Temperature anomalies over the oceans south of about $30^{\circ} \mathrm{N}$ are mostly less strong than over land areas also in the $115 \mathrm{ky}$-simulation. An exception are the Antarctic regions of the oceans, where - specially during the southern winter - temperatures are significantly higher over a large area.

Consistent patterns of temperature anomalies can be found in reconstructions. At 125 kyBP Europe and other northern hemispheric continental areas are affected by higher temperatures see e.g. Kühl (2003); Frenzel et al. (1992), while the sea sur-

2, 1347-1369, 2006

Simulating last interglacial and glacial inception

M. Donat and F. Kasper

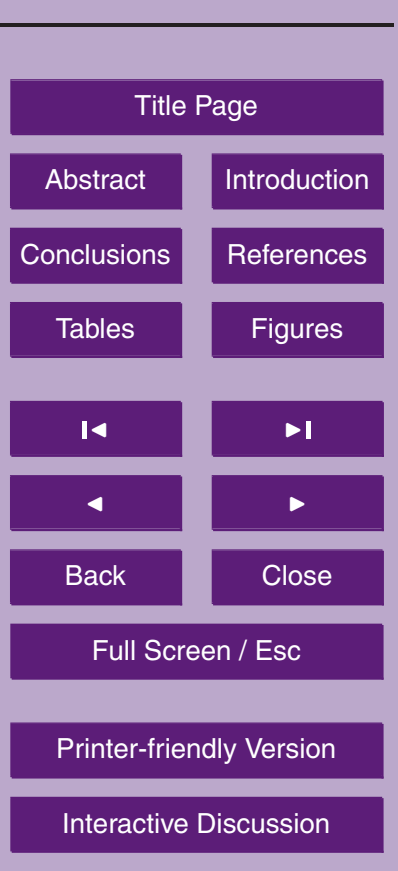


face temperatures differ only marginally from preindustrial reference values (CLIMAP, 1984). The lower temperature values for $115 \mathrm{kyBP}$ also agree with reconstructions (Kukla et al., 2002a). A similar global distribution of the temperature was also found in simulations with a more complex coupled GCM for both dates (Kaspar and Cubasch, 5 2006).

\subsection{Minimum snow- and sea-ice-cover}

The annual minimum of snow- and sea-ice-cover is used here to identify areas with a permanent coverage. These regions play an important role for the accumulation of snow. By increasing the albedo the radiation balance is also changed.

In Fig. 3 the annual minimum snow- and sea-ice-cover is shown for the simulations for $125 \mathrm{ky}$ and $115 \mathrm{ky}$. In both simulations the Arctic sea is permanently ice-covered, as well as the very Northwest of the Atlantic ocean and parts of the northern Pacific. The high snow cover over Greenland is given by the fixed glacier mask. In the $125 \mathrm{ky}$ run, besides Greenland, there is almost no perennial snow cover on continental areas 15 (Fig. 3a).

Compared to that, in the $115 \mathrm{ky}$-run the permanent sea-ice cover reaches farther to the south. Particularly the permanently ice-covered area of the northern Pacific is much larger and reaches farther to the south (Fig. 3b). There is also a larger extent of seaice north of Scandinavia. Furthermore, the ice cover of the Arctic Sea is much thicker 20 than in the $125 \mathrm{ky}$-simulation and additionally covered by snow on wide parts. There are wide perennial snow-covered areas also over the continents in this run. Besides the Himalayan region, this is the case in the Northeast of Asia and of North America. Here, the snow cover extends even in summer until about $50^{\circ} \mathrm{N}$ southwards.

In summary, the simulations show a significantly increased permanent snow- and sea25 ice-cover on the northern hemisphere for 115000 years BP, compared to 125000 years BP. The areas with a perennial snow and ice cover were already identified as regions with particularly large negative temperature anomalies in Sect. 4.1. The large extent of snow cover over North America is consistent with reconstructions (Clark et al., 1993).
2, 1347-1369, 2006

Simulating last interglacial and glacial inception

M. Donat and F. Kasper Title Page

Abstract Introduction Conclusions References

Tables Figures
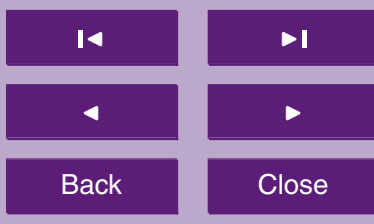

Back

Close

Printer-friendly Version

Interactive Discussion 
However, the perennial snow cover in the Northeast of Asia is not in accordance with reconstructions (Peltier, 1994). Reconstructions for this region show that, although there was permafrost, no glaciation occurred due to a lack of precipitation. In the simulation, there is an overestimation of precipitation in the Asian region which results 5 in the accumulation of snow.

\subsection{Development of the permanent snow- and ice-cover in the $115 \mathrm{ky}$-run}

In the $115 k y$-simulation less energy is available for absorption on the surface in the high northern latitudes as a consequence of the reduced summer insolation. Thus, the surface temperature is lower and because of the weaker long wave radiation the atmo10 spheric layers above are heated less. The lower temperature causes a greater part of precipitation falling as snow, whereof less melts during the cooler summer. Therefore large areas with can be established. Consequently, the surface albedo is increases in these regions and in turn there is again less energy available for heating. Thus, the snow cover can grow and the albedo of the additionally covered area will further increase. This so-called snow-albedo-feedback explains the expansion of snow- and ice-covered areas in the high northern latitudes.

In contrast to that, Kukla et al. (2002b) suggested that the glaciation was caused by the increased temperature gradient between low and high northern latitudes. Consequently, the meridional moisture transport could have been increased. This could have led to the fast build-up of ice-sheets by increased snowfall. However, Kaspar and Cubasch (2006) showed (in their simulations with ECHO-G) that southwards winds from the north pole lead to an amplified cooling in those regions where the accumulation of snow begins.

In Fig. 4 the annual cycle of total precipitation and snowfall is shown for the regions 25 where the snow cover occurs in the $115 \mathrm{ky}$-simulation. Mean monthly quantities are calculated for a region of the north-east of North America $\left(100^{\circ} \mathrm{W}\right.$ to $60^{\circ} \mathrm{W}$ and $50^{\circ} \mathrm{N}$ to $\left.80^{\circ} \mathrm{N}\right)$ and the northern part of Asia $\left(90^{\circ} \mathrm{E}\right.$ to $160^{\circ} \mathrm{E}$ and $50^{\circ} \mathrm{N}$ to $\left.80^{\circ} \mathrm{N}\right)$. For comparison, the same values are calculated for the $125 \mathrm{ky}$-simulation, in which almost no

Simulating last interglacial and glacial inception

M. Donat and F. Kasper Title Page

Abstract

Introduction

Conclusions

Tables References Figures
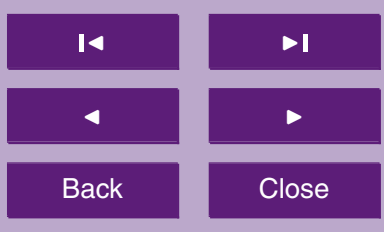

Back

Close

Printer-friendly Version

Interactive Discussion 
perennial snow cover occurs.

In both simulations and both regions the precipitation maximum occurs during summer and the lowest amount of precipitation in winter. There are no significant differences between both simulations concerning annual precipitation as well as precipitation in 5 summer (JJA) or winter (DJF).

In the $115 \mathrm{ky}$-simulation the fraction of precipitation falling as snow is substantially higher during the summer months July and August than in the $125 \mathrm{ky}$-simulation. So there is in fact more snowfall in the $115 \mathrm{ky}$-case in those regions where a permanent snow cover establishes, but the total precipitation quantity is not increased. The greater 10 fraction of snow is mainly caused by the lower temperatures (refer Fig. 2). The fact that the total precipitation (in areas covered by snow during the glacial inception) shows no significant differences between the different simulations already argues against Kukla's (2002b) hypothesis. Nevertheless, the meridional moisture transports was also analyzed. It is calculated as the product of the meridional wind component $v$ and the 15 specific moisture q (Peixoto and Oort, 1992) in each layer and mass-weighted vertically integrated.

The result again shows no significant differences between the simulations for both direction and amount of moisture transport. Furthermore, the relevant regions are rather under the influence of southward transports for both annual mean and during summer 20 (when differences in snowfall are highest). The absolute values of the transport are higher over the snow covered areas in North America, while transport is relatively low over Northeast Asia, as there are quite low pressure gradients on average.

In summary, the analysis showed no increase of precipitation in those regions where a permanent snow cover occured in the $115 \mathrm{ky}$-simulation. The annual mean 25 is in some places even lower compared to the preindustrial reference and the $125 \mathrm{ky}$ simulation. The comparison of the annual cycles of precipitation for the $115 \mathrm{ky}$ - and the $125 \mathrm{ky}$-case shows as the most distinctive difference a significant decrease of summer snowfall for $125 \mathrm{ky}$, while the fraction of precipitation as snow in the $115 \mathrm{ky}$-simulation remains relatively high also during the summer months. Overall, there is more
2, 1347-1369, 2006

Simulating last interglacial and glacial inception

M. Donat and F. Kasper

Title Page

Abstract Introduction

Conclusions References

Tables Figures

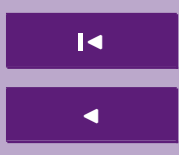

$>\mathbf{I}$

Back

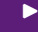

Close

Full Screen / Esc

Printer-friendly Version

Interactive Discussion 
snowfall in the relevant regions in this simulation. The connection between increased meridional moisture transport and increased precipitation as suggested by Kukla et al. (2002b) as a reason for the increased expansion of snow could not be approved on the basis of this simulations.

5 Due to the - mainly during the (northern) summer - reduced solar insolation in high northern latitudes, temperature is considerably lower in this region. This leads on the one hand to a greater fraction of precipitation falling as snow and on the other hand to less melting of snow. This effect is furthermore amplified by the snow-albedo-feedback. In some regions the permanent snow cover reaches farther to the south than in other 10 regions. E.g. western Europe is affected by advection of air from the Atlantic ocean. Thus, temperature is higher than in other regions on the same latitudes and no perennial snow cover is established.

\section{Transient simulation}

Due to the computational efficiency of the Planet Simulator, it is feasible to run a transient simulation of the transition from the interglacial into the glacial. Such a run with a continuous variation of the insolation conditions was performed for the interval from 125000 years BP until 115000 years BP, accelerated by a factor of 10 . Thus, the real period of 10000 years was computed within 1000 simulation years. Such an acceleration of the orbital forcing was suggested by Jackson and Broccoli (2003) and Lorenz and Lohmann (2004). It can be problematic as the sub-systems might react with different time-lags. Lunt et al. (2006, this special issue) showed that accelerated simulations behave in a damped fashion, but with no phase-lag compared to the nonaccelerated simulation. The Planet Simulator typically reaches an equilibrium state

much faster than the typical periods of changes in the orbital parameters. Therefore an accelerated simulation is justifiable and allows at least a rough estimation of the transition into the glaciation.

2, 1347-1369, 2006

Simulating last interglacial and glacial inception

M. Donat and F. Kasper Title Page

Abstract

Introduction

Conclusions

Tables References Figures

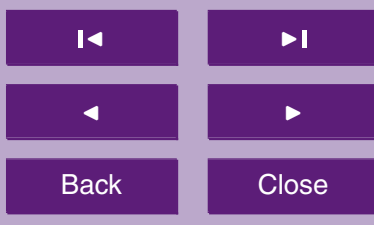

Full Screen / Esc

Printer-friendly Version

Interactive Discussion 
The temporal development of the global mean temperature and the mean solar insolation during summer (JJA) at $65^{\circ} \mathrm{N}$ are shown in Fig. 5 together with the temperatures of the equilibrium runs. Around $125 \mathrm{kyBP}$ summer insolation in the high northern latitudes is close to its maximum and starts to decrease. The global mean temperature 5 remains at its maximum values of about $285.5 \mathrm{~K}$ until approximately $122 \mathrm{kyBP}$. Then the temperature starts to decrease until the end of the simulation. It drops to $284.8 \mathrm{~K}$. The difference between the temperatures $125 \mathrm{kyBP}$ and $115 \mathrm{kyBP}$ is slightly smaller than in the equilibrium runs. At $115 \mathrm{kyBP}$ the temperature in the transient simulation is about $0.2 \mathrm{~K}$ warmer relative to the equilibrium run. This damped behavior could be due 10 to the acceleration of the boundary conditions, but also just to their transient variation. The global snow volume remains initially stable on its minimum. At approx. $123 \mathrm{kyBP}$ it starts to increase significantly, mainly on the northern hemisphere. Until approx. 123 kyBP summer insolation in high northern latitudes is still sufficiently high to prevent the accumulation of snow. From then, summer insolation declines below a critical 15 value, an increase of snow volume begins and continues until the end of the simulation. With a time lag the described decrease of the global mean temperature begins. The contrary trends of global mean temperature and snow volume are shown in Fig. 6. Mean temperature decreases with increasing snow volume.

\section{Summary and conclusions}

20 We have applied the Planet Simulator to simulate the climate of the Eemian interglacial (125 kyBP) and the subsequent glacial inception (115 kyBP). The simulations have been performed as equilibrium runs and also as a transient simulation, accelerated by factor 10 . As boundary conditions only orbital parameters were modified and thus, the seasonal and latitudinal distribution of insolation.

25 The results show that the model is partly successful in qualitatively simulating the climatic conditions of these periods in agreement with reconstructions and simulations with more complex AOGCMs.
2, 1347-1369, 2006

Simulating last interglacial and glacial inception

M. Donat and F. Kasper Title Page

Abstract Introduction Conclusions References

Tables Figures

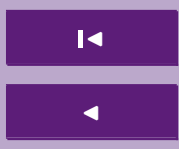
$\rightarrow 1$ 
The strongest response to the insolation change is simulated when all sub-systems are activated: the mixed-layer ocean, the sea-ice- and the vegetation model. Thus, the results confirm that additional feedbacks are essential for simulating the expansion of snow cover and the related cooling.

5 The widest expansion of permanent snow cover in the $115 \mathrm{ky}$-simulation was found in the northeastern part of North America as well as in the Northeast of Asia. The temperature in mid and high northern latitudes is significantly reduced relative to a reference run under preindustrial conditions. In the $125 \mathrm{ky}$-simulation the temperatures are higher especially over continental areas and almost no permanent snow cover oc10 curs.

The expansion of snow cover in the $115 \mathrm{ky}$-simulation is mainly caused by the lower summer temperatures in high northern latitudes. Consequently, a larger fraction of precipitation falls as snow and less snow can melt. The assumption that the increased meridional temperature gradient leads to a stronger moisture transport and consequently to increased snowfall, could not be confirmed with these simulations. In our Planet Simulator experiments for the glacial inception perennial snow cover occurs also over Northeast Asia which is inconsistent to reconstructions. This is caused by an overestimation of precipitation in this region that also occurs in the preindustrial simulation. Model experiments with more complex GCMs (Kaspar and Cubasch, 2006) or EMICs (Kubatzki et al., 2006) led to a regional distribution of perennial snow cover in better agreement with reconstructions.

The transient simulation of the whole interval from $125 \mathrm{kyBP}$ to $115 \mathrm{kyBP}$ shows that snow volume starts to increase after summer insolation in high northern latitudes falls below a critical value. With increasing snow cover, the global mean temperature decreases. In the transient simulation the global temperature at $115 \mathrm{kyBP}$ is about $0.2 \mathrm{~K}$ warmer than in the equilibrium run.

The simulations with the Planet Simulator show a far minor temperature difference between the selected periods compared to ice-core reconstructions or simulations with more complex models. This might be due to its reduced complexity and also to the

Simulating last interglacial and glacial inception

M. Donat and F. Kasper

Title Page

Abstract

Introduction

Conclusions

Tables References Figures
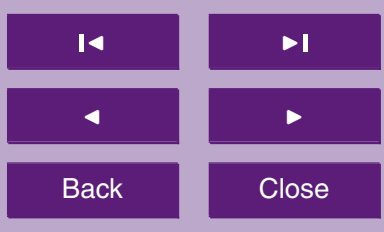

Back

Close

Printer-friendly Version

Interactive Discussion 
low resolution applied in this study (approx. 5.6, 5 vertical levels). However, the main results correspond qualitatively to the cited references and thus show that this coupled GCM of reduced complexity is at least capable to provide a rough estimation of the climatic conditions.

5 Acknowledgements. The Planet Simulator was developed and provided by the Meteorological Institute of the University of Hamburg, working group Theoretical Meteorology (http: //www.mi.uni-hamburg.de/plasim). We are especially grateful to F. Lunkeit for his friendly technical support.

\section{References}

Berger, A. L.: Long-term variations of daily insolation and Quarternary climate changes, J. Atmos. Sci 35, 2362-2367, 1978. 1349, 1350

Berger, A. L., Loutre, M.-F., Kaspar, F., and Lorenz, S. J.: Insolation during interglacials, in: The climate of past interglacials, edited by: F. Sirocko, T. Litt, M. Claussen, M. F. Sánchez-Goñi, Developments in Quarternary Sciences, Vol. 7, Ch. 33, Elsevier, in press, 2006. 1349

Clark, P. U., Clague, J. J., Curry, B. B., Dreimanis, A., Hicock, S. R., Miller, G. H., Berger, G. W., Eyles, N., Lamothe, M., Miller, B. B., Mott, R. J., Oldale, R. N., Stea, R. R., Szabo, J. P., Thorleifson, L. H., and Vincent, J.-S.: Initiation and development of the Laurentide and Cordilleran ice sheets following the last interglaciation, Quaternary Sci. Rev., 12, 79-114, 1993. 1354

CLIMAP Project Members: The last interglacial ocean, Quarternary Research, 21, No. 2, 123224, 1984. 1354

Fraedrich, K., Jansen, H., Kirk, E., Luksch, U., and Lunkeit, F.: The Planet Simulator: Towards a user friendly model, Meteorologische Zeitschrift, 14, 299-304, 2005. 1348, 1349, 1350

Frenzel, B., Pecsi, M., and Velichko, A. A.: Atlas of paleoclimates and paleoenvironments of the northern hemisphere, Late pleistocene - holocene, Gustav Fischer Verlag, Stuttgart, 1992. 1353

Jackson, C. S. and Broccoli, A. J.: Orbital forcing of Arctic climate: mechanisms of climate response and implications for continental glaciation, Clim. Dyn., 21, 539-557, 2003. 1357

Kaspar, F. and Cubasch, U.: Simulations of the Eemian interglacial and the subsequent glacial

Simulating last interglacial and glacial inception

M. Donat and F. Kasper Title Page

Abstract

Introduction

Conclusions

References

Tables

Figures
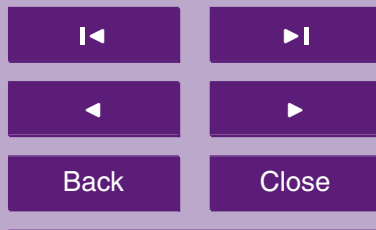

Back

Close

Full Screen / Esc

Printer-friendly Version

Interactive Discussion 
inception with a coupled ocean-atmosphere general circulation model, in: The climate of past interglacials, edited by: Sirocko, F., Litt, T., Claussen, M., Sánchez-Goñi, M. F. Developments in Quarternary, Sciences, Vol. 7. Elsevier, in press, 2006. 1349, 1354, 1355, 1359

Khodri, M., Leclaine, Y., Ramstein, G., Braconnot, P., Marti, O., and Cortijo, E.: Simulating 5 the amplification of orbital forcing by ocean feedbacks in the last glaciation, Nature, 410, 570-574, 2001. 1349

Kubatzki, C., Claussen, M., Calov, R., and Ganopolski, A.: Modelling the end of an Interglacial (MIS 1, 5, 7, 9, 11), in: The climate of past interglacials, edited by: F. Sirocko, T. Litt, M. Claussen, M.F. Sánchez-Goñi, Developments in Quarternary Sciences, Vol. 7. Elsevier, in 10 press, 2006. 1349, 1359

Kühl, N.: Die Bestimmung botanisch-klimatologischer Transferfunktionen und die Rekonstruktion des bodennahen Klimazustandes in Europa während der Eem-Warmzeit, Dissertationes Botanicae, 375, pp. 149, 2003. 1353

Kukla, G. J.: The Last Interglacial, Science, 287, 987-988, 2000.

15 Kukla, G. J., Bender, M. L., de Beaulieu; J. L., Bond, G., Broecker, W. S., Cleveringa, P., Gavin, J. E., Herbert, T. D., Imbrie, J., Jouzel, J., Keigwin, L. D., Knudsen, K. L., McManus, J. F., Merkt, J., Muhs, D. R., and Müller, H.: Last Interglacial Climates, Quarternary Research, 58, 2-13, 2002a. 1354

Kukla, G. J., Clement, A. C., Cane, M. A., Gavin, J. E., and Zekiak, S. E.: Last Interglacial and

20 Early Glacial ENSO, Quarternary Research, 58, 27-31, 2002b. 1355, 1357

Lorenz, S. J. and Lohmann, G.: Acceleration technique for Milankovitch type forcing in a coupled atmosphere-ocean circulation model: method and application for the Holocene, Clim. Dyn., 23, 727-743, 2004. 1357

Lunt, D. J., Williamson, M. S., Valdes, P. J., and Lenton, T. M.: Comparing transient, accelerated, and equilibrium simulations of the last 30000 years with the GENIE-1 model, Climate of the Past, 2, 221-235, special issue on "Modelling Late Quaternary Climate", 2006. 1357

Milankovich, M.: Kanon der Erdbestrahlung und seiner Anwendung auf das Eiszeitenproblem, Editions Speciales 133, Academie Royal Serbe, 33, pp.633, Belgrade, 1941. 1348

Peixoto, J. P. and Oort, A. H.: Physics of Climate, American Institute of Physics, 1992. 1356

30 Peltier, W. R.: Ice Age Paleotopography, Science, New Series, Vol. 265, No. 5169, 195-201, 1994. 1355

Petit, J. R., Jouzel, J., Raynaud, D., Barkov, N. I., Barnola, J. M., Basile, I., Bender, M., Chapellaz, J., Davis, J., Delaygue, G., Delmotte, M., Kotlyakov, V. M., Legrand, M., Lipenkov, V. M.,

\section{Simulating last interglacial and glacial inception}

M. Donat and F. Kasper

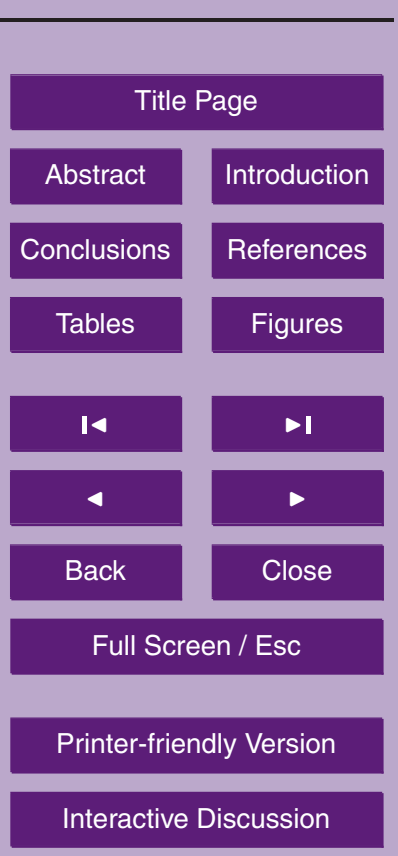


Lorius, C., Pepin, L., Ritz, C., Saltzman, E., and Stievenard, M.: Climate and atmospheric history of the past 420000 years from the Vostok ice core, Nature, 399, 429-436, 1999. 1350

Vettoretti, G. and Peltier, W. R.: Sensitivity of glacial inception to orbital and greenhouse gas climate forcing, Quarternary Science Reviews, 23, 499-519, 2004. 1349

Vettoretti, G. and Peltier, W. R.: Post-Eemian Glacial Inception. Part I: The Impact of Summer Seasonal Temperature Bias, Journal of Climate, Vol. 16, No. 6, 889-911, 2003. 1349
2, 1347-1369, 2006

\section{Simulating last interglacial and glacial inception}

M. Donat and F. Kasper

\section{Title Page}

Abstract

Introduction

Conclusions

References

Tables

Figures

14

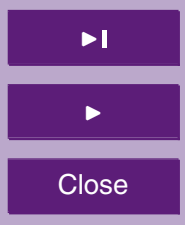

Back

Close

Full Screen / Esc

Printer-friendly Version

Interactive Discussion 
Table 1. Configuration of the equilibrium simulations. In the simulation name "A" stands for computation of the atmosphere, "O" marks the coupled ocean and sea-ice model. If the vegetation model is switched on, the name of the simulation contains a "V".

\begin{tabular}{|c|c|c|c|}
\hline Simulation & Ocean/Sea-Ice & Vegetation & kyBP \\
\hline \multicolumn{4}{|c|}{ atmosphere only, without any coupled sub-models } \\
\hline A/115 ky & off & off & 115 \\
\hline $\mathrm{A} / 125 \mathrm{ky}$ & off & off & 125 \\
\hline A/REF & off & off & 0 \\
\hline \multicolumn{4}{|c|}{ atmosphere coupled to mixed-layer ocean and sea-ice mode } \\
\hline $\mathrm{AO} / 115 \mathrm{ky}$ & on & off & 115 \\
\hline $\mathrm{AO} / 125 \mathrm{ky}$ & on & off & 125 \\
\hline AO/REF & on & off & 0 \\
\hline \multicolumn{4}{|c|}{ atmosphere coupled to vegetation model } \\
\hline AV/115 ky & off & on & 115 \\
\hline AV/125 ky & off & on & 125 \\
\hline AV/REF & off & on & 0 \\
\hline \multicolumn{4}{|c|}{$\begin{array}{l}\text { atmosphere coupled to mixed-layer ocean, sea-ice and } \\
\text { vegetation model }\end{array}$} \\
\hline AOV/115 ky & on & on & 115 \\
\hline AOV/125 ky & on & on & 125 \\
\hline AOV/REF & on & on & 0 \\
\hline
\end{tabular}

\section{Simulating last interglacial and glacial inception}

M. Donat and F. Kasper Title Page

\begin{tabular}{c|c|}
\hline Abstract & Introduction \\
\hline Conclusions & References \\
\hline Tables & Figures \\
\hline I4 & $\bullet \mathbf{I}$ \\
\hline 4 & $\bullet$ \\
\hline Back & Close \\
\hline Full Screen / Esc \\
\hline Printer-friendly Version
\end{tabular}




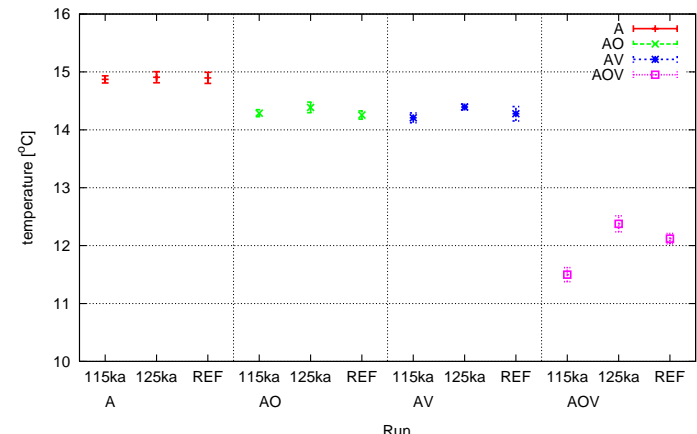

(a) global

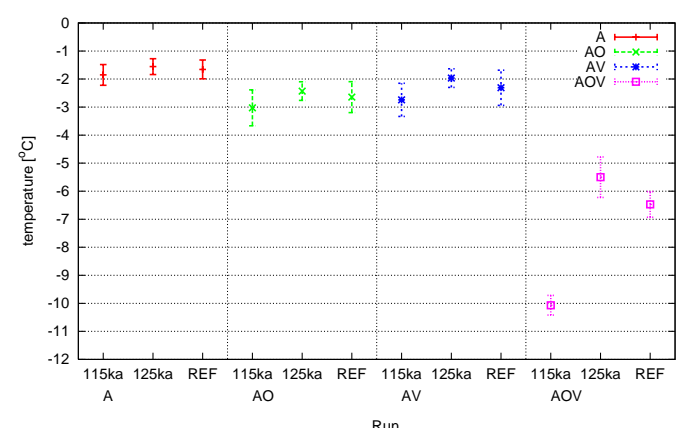

(b) $50^{\circ} \mathrm{N}$ to $80^{\circ} \mathrm{N}$

Fig. 1. Near-surface temperatures of the simulations with different settings for the couplings. (a) global mean temperature and (b) mean temperature in mid to high northern latitudes.

\section{Simulating last interglacial and glacial inception}

M. Donat and F. Kasper Title Page

\begin{tabular}{|c|c|}
\hline Abstract & Introduction \\
\hline Conclusions & References \\
\hline Tables & Figures \\
\hline I4 & $\bullet \mathbf{I}$ \\
\hline 4 & $\triangleright$ \\
\hline Back & Close \\
\hline Full Screen / Esc
\end{tabular}

Printer-friendly Version

Interactive Discussion 


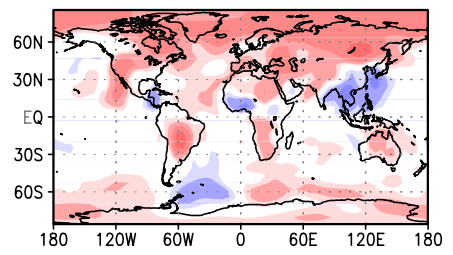

(c) JJA $125 \mathrm{kyBP}$

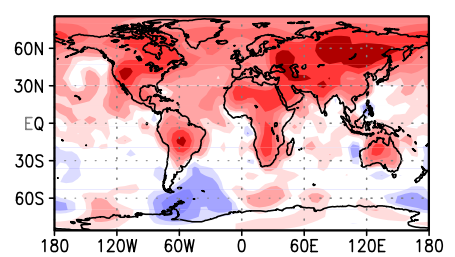

(e) DJF $125 \mathrm{kyBP}$

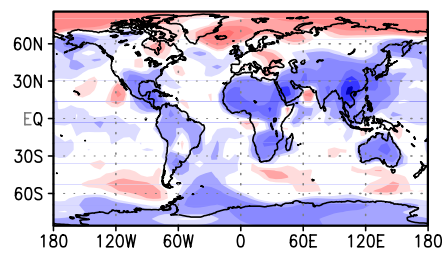

(f) DJF 115 kyBP
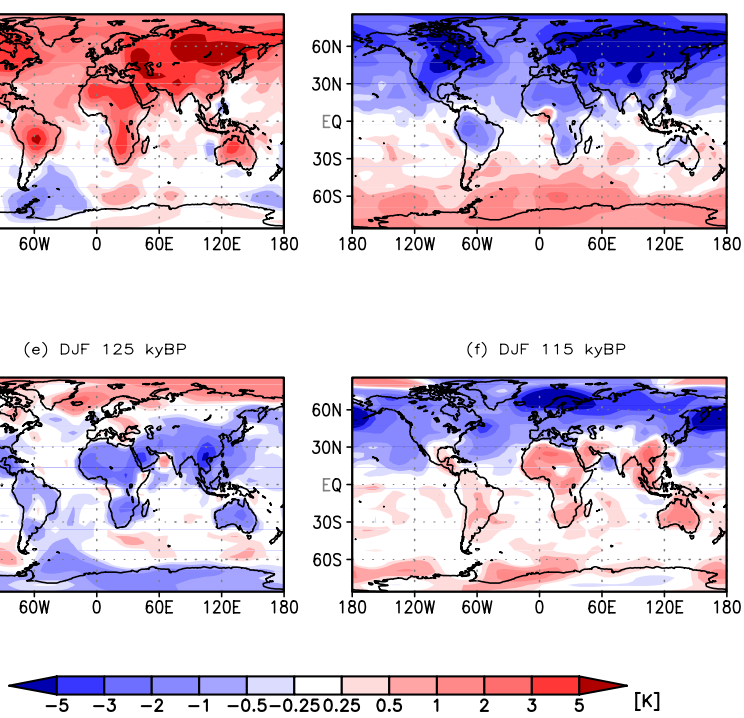

Fig. 2. Anomalies of near-surface temperature $(\mathrm{T} 2 \mathrm{~m})$ relative to $R E F$ in $\mathrm{K}$. Left column: for the run $125 \mathrm{ky}$ (a) annual mean, (c) JJA, (e) DJF. And accordingly right for $115 \mathrm{ky}$ (b) annual mean, (d) JJA and (f) DJF.
2, 1347-1369, 2006

\section{Simulating last interglacial and glacial inception}

M. Donat and F. Kasper

\section{Title Page}

Abstract

Introduction

Conclusions

References

Tables

Figures

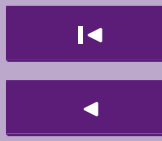

Back

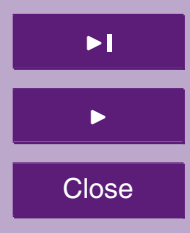

Full Screen / Esc

Printer-friendly Version

Interactive Discussion 
(a) $125 \mathrm{kyBP}$
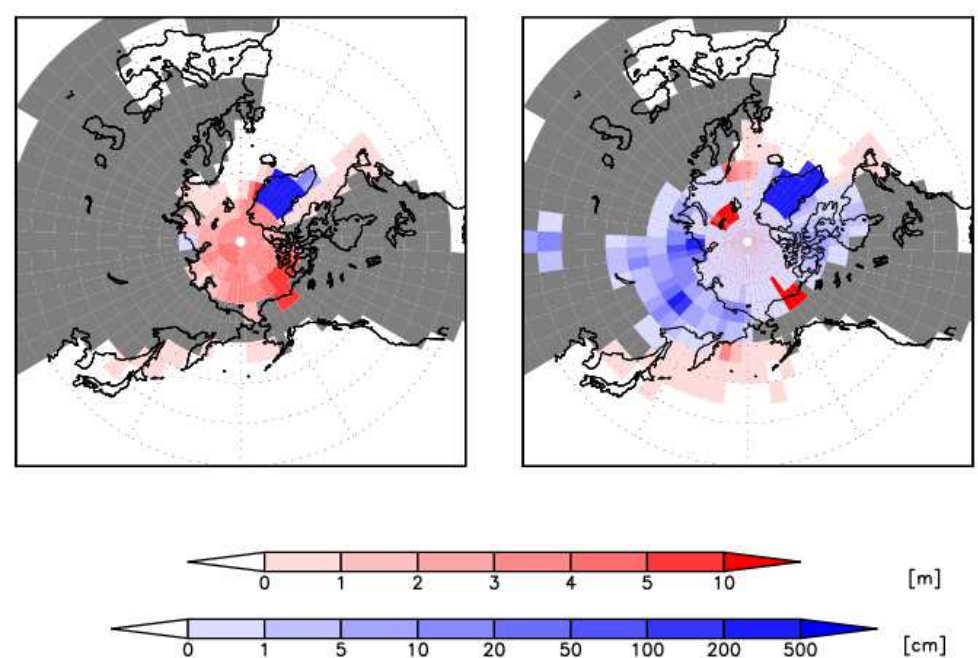

100

(b) $115 \mathrm{kyBP}$

\section{Simulating last interglacial and glacial inception}

M. Donat and F. Kasper

\begin{tabular}{|c|c|}
\hline \multicolumn{2}{|c|}{ Title Page } \\
\hline Abstract & Introduction \\
\hline Conclusions & References \\
\hline Tables & Figures \\
\hline I4 & \\
\hline 4 & $>$ \\
\hline Back & Close \\
\hline Full Screen / Esc
\end{tabular}

Printer-friendly Version

Interactive Discussion 


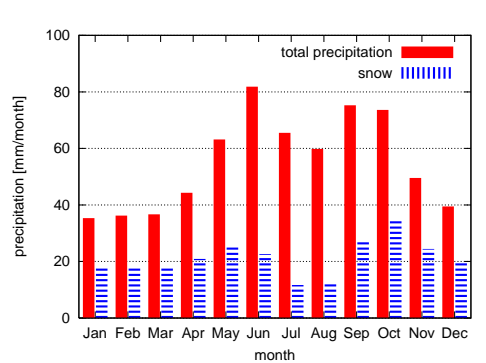

(a) North America $125 \mathrm{ky}$

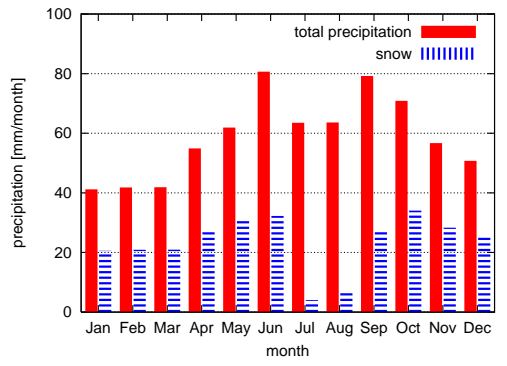

(c) Northeast Asia $125 \mathrm{ky}$

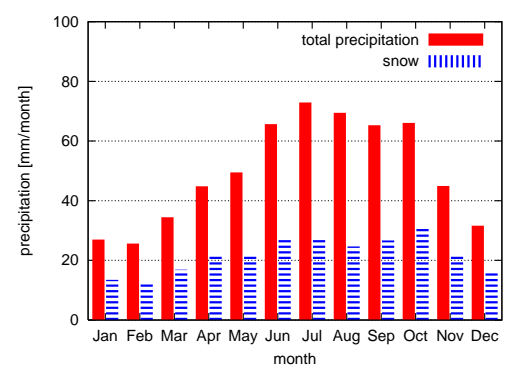

(b) North America $115 \mathrm{ky}$

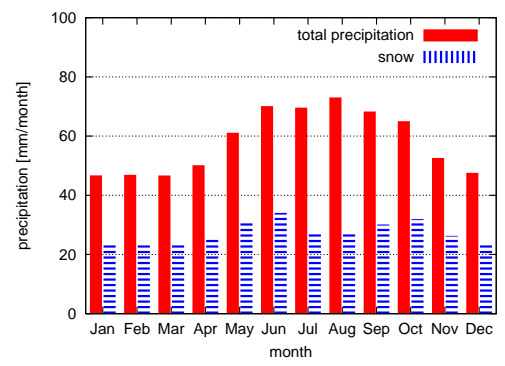

(d) Northeast Asia $115 \mathrm{ky}$
Simulating last interglacial and glacial inception

M. Donat and F. Kasper

Title Page

Abstract

Introduction

Conclusions

References

Tables

Figures

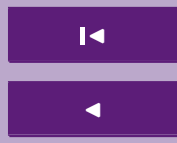

Back

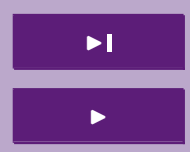

Close

Full Screen / Esc

Printer-friendly Version

Interactive Discussion 


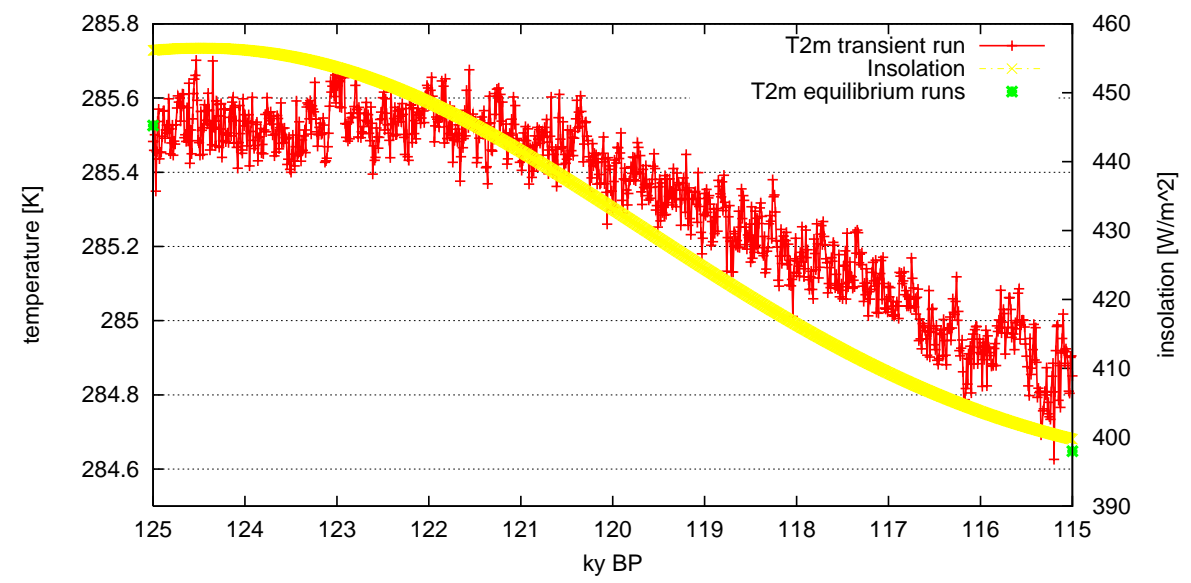

\section{Simulating last interglacial and glacial inception}

M. Donat and F. Kasper

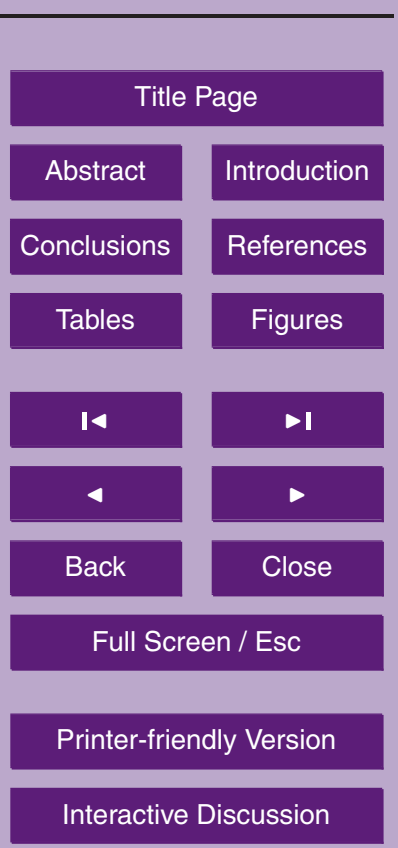




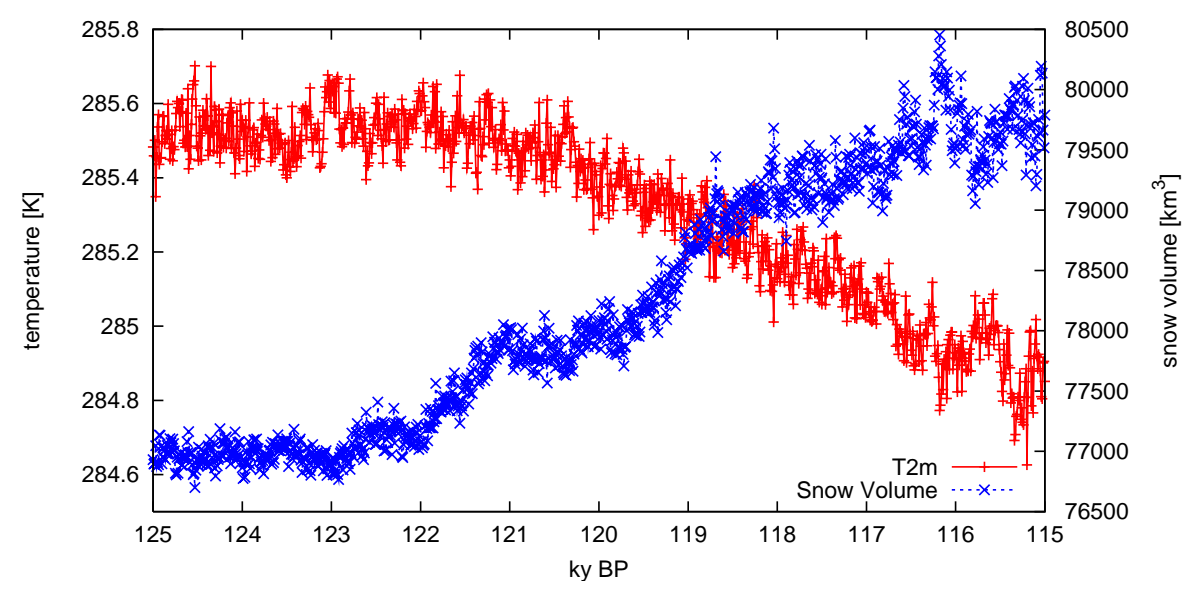

\section{Simulating last interglacial and glacial inception}

M. Donat and F. Kasper

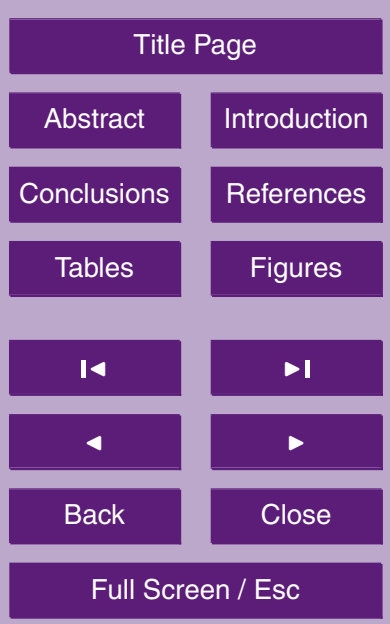

Printer-friendly Version

Interactive Discussion 